\title{
Bernadeta Baran
}

Uniwersytet Ekonomiczny we Wrocławiu

e-mail: bernadeta.baran@ue.wroc.pl

\section{BREXIT A SOFT POWER UNII EUROPEJSKIEJ}

\section{BREXIT VS. THE EUROPEAN UNION SOFT POWER}

DOI: $10.15611 / \mathrm{pn} .2018 .539 .02$

JEL Classification: C71, D72, F02

Streszczenie: Celem artykułu jest wyznaczenie pozycji UE w obszarze soft power, wskazanie udziału Wielkiej Brytanii w kreowaniu tej siły i omówienie następstw brexitu dla międzynarodowej roli UE. UE jest jednym z najważniejszych uczestników stosunków międzynarodowych. Swoją pozycję buduje, wykorzystując zarówno „twarde” instrumenty przymusu, jak i oddziałując na otoczenie zewnętrzne za pomocą „łagodnych” środków o charakterze politycznym, dyplomatycznym, ekonomicznym, kulturowym. Jednak w obliczu dokonujących się przemian w środowisku międzynarodowym (rosnąca siła państw Azji) i w związku z utratą jednego ze swoich najważniejszych członków, jej potęga zostanie osłabiona. Brexit może też stać się początkiem rozpadu UE, jeśli nie zostaną podjęte działania wzmacniające jedność Europy. Konieczne jest m.in. zainicjowanie procesu przyspieszającego modernizację struktur, mechanizmów zarządzania i podejmowania decyzji oraz wzmocnienie polityki zagranicznej i obrony.

Słowa kluczowe: brexit, soft power, międzynarodowa pozycja UE.

Summary: The aim of the article is to determine the position of the EU in the area of soft power, to indicate the participation of the United Kingdom in the creation of this power and to discuss the consequences of brexit for the international role of the EU. The EU is one of the most important participants in international enviroment. It builds its position using both "hard" instruments and soft measures of political, diplomatic, economic and cultural nature. However, in the face of ongoing changes in the international environment (the growing power of Asian states) and in connection with the loss of one of its most important members, its power will be weakened. Brexit could also start the EU breakdown process. To prevent this it is necessary, among other things, to speed up the modernisation of structures, management and decision-making mechanisms, and to strengthen foreign and defence policy.

Keywords: brexit, soft power, international position of the EU. 


\section{Wstęp}

Międzynarodowa rola jednostki politycznej wynika z jej spójnego systemu działań i zachowań w relacji ze światem zewnętrznym, przy wykorzystaniu posiadanego potencjału i zgodnie z wyznawanym katalogiem zasad i wartości [Antczak 2012]. UE jest jednym z najważniejszych uczestników stosunków międzynarodowych. Swoją pozycję buduje wykorzystując zarówno „twarde” (hard) instrumenty przymusu, jak i oddziałując na otoczenie zewnętrzne za pomocą „łagodnych” (soft) środków o charakterze politycznym, dyplomatycznym, ekonomicznym, kulturowym, przy czym zdecydowaną większość celów politycznych osiąga dzięki tym drugim [Parzymies 2009]. Krajem, który w znacznym stopniu kształtuje miękką siłę UE, jest Wielka Brytania. Jej wyjście ze struktur europejskich może pociągnąć za sobą negatywne konsekwencje geopolityczne, osłabiając wewnętrzną spójność UE i jej pozycję w środowisku międzynarodowym. $\mathrm{Z}$ drugiej strony brexit oznacza koniec brytyjskiego weta wobec przyspieszania integracji, co może stworzyć warunki do zdynamizowania procesu integracji europejskiej. Przewiduje się jednak, że proces ten będzie przebiegać w nowej formule: „Unii wielu prędkości”.

Celem artykułu jest wyznaczenie pozycji UE w obszarze soft power, wskazanie udziału Wielkiej Brytanii w kreowaniu tej siły i omówienie następstw brexitu dla międzynarodowej roli UE. Analiza zostanie przeprowadzona w oparciu o dane wskaźnikowe określające pozycję jednostek politycznych w środowisku międzynarodowym i przy wykorzystaniu dostępnej literatury przedmiotu.

\section{Koncepcja miękkich czynników siły}

Siła jednostki politycznej jest zjawiskiem wielowymiarowym i relatywnym. W literaturze nie ma jednej, powszechnie uznanej definicji potęgi (power) oraz sposobu jej pomiaru, ale można przyjąć, że potęga to zdolność do osiągania własnych celów, czyli umiejętność wpływania na innych w celu osiągnięcia pożądanych rezultatów [Łoś 2016]. W literaturze wskazuje się na różne czynniki określające potęgę państwa. Dla Organskiego [1967] są to głównie czynniki materialne, tj. geograficzne (położenie geopolityczne, wielkość terytorium, ukształtowanie topograficzne, klimat); zasoby naturalne (bogactwa naturalne i kontrola ich wydobycia); czynniki demograficzne (liczba ludności w wieku produkcyjnym, liczba poborowych); czynniki rozwoju ekonomicznego (dochód państwa i dochód per capita, zatrudnienie poza rolnictwem, stopień urbanizacji kraju); czynniki polityczne (strategia polityki zagranicznej, skuteczność dyplomacji i propagandy, wpływ polityki na gospodarkę, rola armii, pozycja rządu), identyfikacja i lojalność obywateli wobec państwa. Stoessinger [1969, za: Łoś 2016] w większym stopniu uwzględnia czynniki pozamaterialne, m.in. charakter narodowy (sposób postrzegania przez naród samego siebie oraz innych uczestników stosunków międzynarodowych) i morale narodowe (wytrwałość 
w dążeniu do wyznaczonego celu), których źródeł upatruje w kulturze, doświadczeniu historycznym i strukturze socjalnej narodu. Jako istotne wymienia też ideologię (ocena bliskiej przeszłości), wizję wspólnej przyszłości oraz przywództwo narodowe. Komponenty twarde traktuje natomiast jak potencjał, którego stopień wykorzystania zależy od jakości elementów pozamaterialnych.

Tabela 1. Wielosektorowość potęgi wg J. Nye’a

\begin{tabular}{|l|l|l|l|}
\hline \multicolumn{1}{|c|}{ Segmenty potęgi } & \multicolumn{1}{|c|}{$\begin{array}{c}\text { Formy zachowań } \\
\text { politycznych }\end{array}$} & \multicolumn{1}{|c|}{$\begin{array}{c}\text { Główne instrumenty } \\
\text { oddziaływania }\end{array}$} & \multicolumn{1}{|c|}{$\begin{array}{c}\text { Formy polityki } \\
\text { państwowej }\end{array}$} \\
\hline Potęga wojskowa & $\begin{array}{l}\text { Przymus, } \\
\text { odstraszanie, ochrona }\end{array}$ & Groźba, zastraszanie & $\begin{array}{l}\text { Akcje prewencyjne, } \\
\text { wojna, sojusze }\end{array}$ \\
\hline Potęga ekonomiczna & Perswazja i przymus & $\begin{array}{l}\text { Środki płatnicze } \\
\text { i sankcje ekonomiczne }\end{array}$ & $\begin{array}{l}\text { Pomoc humanitarna, } \\
\text { łopownictwo, sankcje }\end{array}$ \\
\hline $\begin{array}{l}\text { Miękkie środki } \\
\text { oddziaływania } \\
\text { politycznego }\end{array}$ & $\begin{array}{l}\text { Atrakcyjność, } \\
\text { ustanawianie agend } \\
\text { (przyciąganie oraz } \\
\text { przekonywanie) }\end{array}$ & $\begin{array}{l}\text { Wartości, kultura, } \\
\text { jakość polityki, } \\
\text { instytucjonalizm }\end{array}$ & $\begin{array}{l}\text { Dyplomacja społeczna, } \\
\text { multilateralizm }\end{array}$ \\
\hline
\end{tabular}

Źródło: [Nye 2007, s. 62].

Autorem zwartej koncepcji miękkich czynników siły jest Nye [2007], który wyróżnił i zdefiniował trzy segmenty potęgi: wojskową, ekonomiczną i miękkie środki oddziaływania (tab. 1). W ujęciu Nye’a, soft power kładzie nacisk na zdolność osiągania celów dzięki własnej atrakcyjności, co może się przejawiać na różne sposoby, m.in. w formie wywierania wpływów kulturowych, promowania własnych wartości polityczno-ideologicznych, sprawowania przywództwa w sferze wiedzy i komunikacji, rozpowszechniania zasad prawa międzynarodowego, stosowania wielostronnej dyplomacji, rozwijania współpracy gospodarczej. W soft power przedkłada się negocjacje, dyplomację i prawo międzynarodowe ponad użycie siły, zachętę ponad przymus i działania wielostronne (multilateralne) nad jednostronne. Zarówno twarde, jak i miękkie czynniki siły są ważnymi atrybutami potęgi, aczkolwiek soft power jest coraz częściej wykorzystywana przez globalnych graczy, którym brakuje tzw. „twardego podbrzusza” [Milczarek 2003]. To właśnie prawo międzynarodowe, arbitraż organizacji międzynarodowych, zasady „spokojnego mocarstwa” są podstawowymi determinantami oddziaływania UE w środowisku międzynarodowym ${ }^{1}$. Atrakcyjność UE przejawia się też w aspekcie kulturowym (powszechna znajomość w świecie europejskich języków oraz szeroko rozumianego dorobku kulturowo-cywilizacyjnego), a także aksjologicznym, dzięki ogólnemu uznaniu „wartości europejskich" za wzorcowe [Parzymies 2009].

${ }^{1}$ Należy zaznaczyć, że przewaga elementów soft power w międzynarodowych działaniach Unii nie czyni z niej bynajmniej „,mocarstwa jednowymiarowego. Szerzej: [Barburska 2016]. 


\section{Soft power Unii Europejskiej i Wielkiej Brytanii}

Potęga jednostki politycznej w aspekcie twardej siły (hard power) jest wyznaczana w oparciu o jej poszczególne składniki przy wykorzystaniu dostępnych danych statystycznych (np. wydatki militarne ${ }^{2}$ ). Bardziej skomplikowana jest natomiast ocena potencjału jednostki politycznej w ujęciu wielowymiarowym lub wyłącznie w dziedzinie soft power. Ten niewymierny aspekt mocarstwowości powstaje bowiem w znacznej mierze w sferze subiektywnego odczucia czy tworzonego wrażenia.

Przykładem podejścia wielowymiarowego jest wskaźnik opracowany przez Sułka [2013]. Wskaźnik ten uwzględnia czynniki: ekonomiczny (PKB), militarny (wydatki wojskowe i liczba żołnierzy służby czynnej), demograficzny (liczba ludności) i geograficzny (powierzchnia kraju). Stopa wydatków wojskowych jest traktowana jako waga, którą państwo przykłada do bezpieczeństwa, a potęga ogólna państwa jest syntetycznym wyrażeniem zdolności do działań zbiorowych określonej liczby ludności w określonym czasie i przestrzeni (potęga poszczególnych państw jest ułamkiem potęgi świata, wyrażona w milimirach $[\mathrm{mM}]$ ).

Tabela 2. Potęga 10 najsilniejszych państw świata w 1992, 2003 i 2015 r.

\begin{tabular}{|c|c|c|c|c|c|c|}
\hline \multirow{2}{*}{ Lp. } & \multicolumn{2}{|l|}{1992} & \multicolumn{2}{|l|}{2003} & \multicolumn{2}{|l|}{2015} \\
\hline & państwo & {$[\mathrm{mM}]$} & państwo & {$[\mathrm{mM}]$} & państwo & {$[\mathrm{mM}]$} \\
\hline 1 & USA & 159,676 & USA & 174,418 & USA & 152,204 \\
\hline 2 & Japonia & 67,688 & Chiny & 67,867 & Chiny & 149,963 \\
\hline 3 & Niemcy & 41,543 & Japonia & 53,852 & Indie & 44,858 \\
\hline 4 & Chiny & 37,397 & Niemcy & 34,200 & Japonia & 33,402 \\
\hline 5 & Francja & 29,871 & Indie & 30,817 & Brazylia & 30,149 \\
\hline 6 & Włochy & 27,738 & Francja & 27,542 & Niemcy & 26,324 \\
\hline 7 & Rosja & 26,721 & Wielka Brytania & 25,957 & Rosja & 24,819 \\
\hline 8 & Wielka Brytania & 25,274 & Włochy & 22,984 & Wielka Brytania & 21,630 \\
\hline 9 & Indie & 24,646 & Brazylia & 21,653 & Francja & 21,236 \\
\hline 10 & Brazylia & 22,851 & Kanada & 20,417 & Kanada & 19,194 \\
\hline
\end{tabular}

Źródło: [Białoskórski, Kobryński, Sułek 2017].

Z zestawienia wynika, że Wielka Brytania to jedno z trzech europejskich mocarstw. Jej siła, podobnie jak potęga Francji i Niemiec, uległa jednak osłabieniu, aczkolwiek w najmniejszym stopniu. Gdyby Unię Europejską uznać za oddzielny podmiot (poprzez sumowanie wartości siły dla wszystkich państw członkowskich), zajęłaby drugą pozycję w 2003 r. z wynikiem 182,164 mM i trzecią w 2015 r. (144,892 mM). W takim ujęciu Wielka Brytania kształtowałaby siłę UE w 14\% w 2003 r.

${ }^{2}$ Militarnym wskaźnikiem jest np. Global Firepower Index (MilitaryFactory.com, 2016). 
i w 15\% w 2015 r. Należy też zauważyć istotne zmiany w światowym układzie sił. W ostatnim ćwierćwieczu pozycję lidera, mimo niewielkiego spadku siły, zachowały USA. Tymczasem Chiny odnotowały czterokrotny wzrost swojej potęgi, Indie blisko dwukrotny, a siła Brazylii wzrosła o 32\% (wzrostów doświadczyły też inne państwa rozwijające się, np. Nigeria, Wietnam, Egipt czy Indonezja).

Przykładem innego wskaźnika, który ujmuje moc państw w sposób syntetyczny, uwzględniając zarówno siłę twardą (w większym stopniu), jak i miękką, jest Indeks Mocy Państw [IMP 2017]. Moc państwa jest traktowana jako suma kapitałów: ekonomicznego (wielkość PKB wg PSN, rating kraju, liczba bogatych obywateli), militarnego (wydatki na wojsko, produkcja i sprzedaż broni, wydatki na wojsko w relacji do PKB, wielkość służb mundurowych, posiadanie broni atomowej), geograficznego (powierzchnia), demograficznego (wielkość populacji oraz wskaźnik obciążenia demograficznego osobami 65+), a także efektywności wykorzystania zasobów naturalnych (wielkość energii produkowanej w kraju, samowystarczalność energetyczna), siły kultury (liczba uczelni na liście szanghajskiej) i siły dyplomacji (członkostwo w Radzie Bezpieczeństwa ONZ, członkostwo w najważniejszych organizacjach międzynarodowych i przewodnictwo w organizacjach międzynarodowych). Indeks mocy państw przyjmuje wartości od 0 do 100 pkt, gdzie najpotężniejsze państwo ma największy wskaźnik udziału w całości.

Tabela 3. 10 najpotężniejszych krajów świata według IMP [pkt] oraz potencjał UE

\begin{tabular}{|l|c|c|c|c|c|c|c|c|c|}
\hline \multicolumn{1}{|c|}{ Kraj } & Pozycja & $\begin{array}{c}\text { Indeks } \\
\text { mocy } \\
\text { państw }\end{array}$ & $\begin{array}{c}\text { Indeks } \\
\text { kapitału }\end{array}$ & $\begin{array}{c}\text { Indeks } \\
\text { milita- } \\
\text { ryzacji }\end{array}$ & $\begin{array}{c}\text { Indeks } \\
\text { ziemi }\end{array}$ & $\begin{array}{c}\text { Indeks } \\
\text { zasobów } \\
\text { ludzkich }\end{array}$ & $\begin{array}{c}\text { Indeks } \\
\text { kultury }\end{array}$ & $\begin{array}{c}\text { Indeks } \\
\text { zasobów } \\
\text { naturalnych }\end{array}$ & $\begin{array}{c}\text { Indeks } \\
\text { dyplomacji }\end{array}$ \\
\hline USA & 1 & 16,22 & 13,66 & 31,03 & 7,12 & 4,08 & 24,40 & 7,60 & 6,16 \\
\hline Chiny & 2 & 12,49 & 16,37 & 8,21 & 7,31 & 17,02 & 10,80 & 9,69 & 6,09 \\
\hline Rosja & 3 & 5,25 & 3,18 & 8,99 & 12,75 & 1,87 & 0,60 & 5,33 & 7,79 \\
\hline Indie & 4 & 5,24 & 6,61 & 3,04 & 2,32 & 16,26 & 0,20 & 2,17 & 0,09 \\
\hline Niemcy & 5 & 3,09 & 3,70 & 3,35 & 0,27 & 1,15 & 7,60 & 0,56 & 0,16 \\
\hline Wielka & & & & & & & & & \\
Brytania & 6 & 2,96 & 2,38 & 4,11 & 0,19 & 0,93 & 7,40 & 0,58 & 6,14 \\
\hline Francja & 7 & 2,78 & 2,26 & 4,37 & 0,43 & 0,97 & 4,40 & 0,67 & 7,82 \\
\hline Japonia & 8 & 2,43 & 3,65 & 1,44 & 0,28 & 1,77 & 3,20 & 0,12 & 3,09 \\
\hline Brazylia & 9 & 2,40 & 2,42 & 1,25 & 6,51 & 2,62 & 1,20 & 1,24 & 1,79 \\
\hline Kanada & 10 & 2,03 & 1,51 & 0,82 & 7,08 & 0,55 & 3,80 & 2,23 & 0,16 \\
\hline UE & & 18,42 & 19,0 & 19,80 & 3,06 & 3,30 & 37,80 & 7,88 & 27,43 \\
\hline
\end{tabular}

Źródło: [IMP 2017].

Dziesięć największych potęg tworzą aż trzy państwa europejskie, w tym Wielka Brytania. Jeśli siła UE zostałaby ujęta tak jak wszystkie państwa indeksu i gdyby stała się ona federacją z jednym rządem, to potęga takiego układu hipotetycznie byłaby wyższa niż potęga USA. Moc UE wynosiłaby 18,16 pkt, ale już po wykluczeniu 
Wielkiej Brytanii osiągnęłaby drugą pozycję (15,2 pkt). UE jest potęgą kulturową, niekwestionowanym liderem $\mathrm{w}$ obszarze dyplomacji i ma najwyższy indeks kapitału. Dominuje więc w wybranych sektorach gospodarczych, ale przede wszystkim w obszarze soft power (dużym potencjałem miękkich środków charakteryzują się zarówno poszczególne państwa, jak i sama UE jako symbol zjednoczonej Europy). Potwierdzają to wyniki raportu, publikowanego corocznie przez Portland Communications i University of Southern California [Soft Power 30], który pozycjonuje państwa wyłącznie według miękkiej siły. Punkty przyznawane są w oparciu o sześć kryteriów: rząd, kultura, edukacja, przedsiębiorczość, rozwój cyfrowy i zaangażowanie na arenie międzynarodowej ${ }^{3}$, a dane pochodzą od instytucji państwowych i od respondentów z poszczególnych państw. Do niedawna liderem w tym zestawieniu była Wielka Brytania, ale w 2017 r. pierwsze miejsce zajęła Francja (jej przewaga nad Wielką Brytanią jest co prawda nieznaczna i wynosi 0,03 pkt, ale imponujący jest awans Francji z piątego miejsca rankingu w 2015 r.). Wpływ na ten wynik miała z jednej strony decyzja o wyjściu Wielkiej Brytanii z UE, a z drugiej wybór prezydenta Macrona, którego polityka zyskała aprobatę zarówno krajową, jak i międzynarodową. Dziesięć państw o najwyższym wskaźniku miękkiej siły wg rankingu Soft Power 30 to w kolejności: Francja, Wielka Brytania, USA ${ }^{4}$, Niemcy, Kanada, Japonia, Szwajcaria, Australia, Szwecja, Holandia.

\section{Wpływ brexitu na międzynarodową pozycję UE}

Brexit to wydarzenie bez precedensu, które będzie stanowić ważną cezurę w historii Unii Europejskiej i istotnie wpłynie na jej miejsce w środowisku międzynarodowym. UE straci część potencjału gospodarczego (utrata drugiej największej gospodarki) $)^{5}$, finansowego (utrata drugiego największego płatnika netto do wspólnego budżetu), politycznego (utrata kraju o najsprawniejszej dyplomacji i największym soft power, stałego członka w Radzie Bezpieczeństwa ONZ) i militarnego (utrata kraju o największych wydatkach militarnych ${ }^{\wp}$, co osłabi jej rolę w systemie euroatlan-

\footnotetext{
${ }^{3}$ Uwzględniane są m.in.: wkład danego państwa w ogólny rozwój świata, zasięg jego kultury, poziom realizacji przez rząd podstawowych wartości (pokój, poszanowanie prawa człowieka i demokracja), panujący w kraju klimat dla biznesu i innowacji, a także poziom edukacji społeczeństwa oraz możliwości kształcenia się. Pod uwagę bierze się także inne czynniki, np. wyniki państwa w sporcie czy liczbę restauracji z gwiazdkami Michelina.

${ }^{4}$ Miękka siła USA spadła w odniesieniu do poprzednich zestawień głównie na skutek ostatniej kampanii prezydenckiej i jakości dyskursu w polityce.

${ }^{5}$ Szacuje się, że w rozrachunku ekonomicznym to Wielka Brytania poniesie większe koszty niż UE: rynek UE jest ważniejszy dla Wielkiej Brytanii pod względem powiązań gospodarczych niż rynek brytyjski dla UE. Ok. 50\% brytyjskiego eksportu skierowane jest to Unii, podczas gdy tylko ok. 10\% unijnego do Wielkiej Brytanii [Global Counsel 2015].

${ }^{6}$ Wielka Brytania to szósty kraj na świecie (po USA, Chinach, Arabii Saudyjskiej, Rosji i Indiach) pod względem wysokości wydatków militarnych - w 2017 r. wyniosły one 50,7 mld USD, [International Institute for Strategic Studies 2018].
} 
tyckim i w budowie nowego ładu międzynarodowego. Swoją pozycję wzmocnią tym samym m.in. Chiny i Rosja, co utrwali proces przesuwania się środka ciężkości w ramach globalnego ładu w kierunku Azji. Brexit naruszy też polityczną równowagę, jaką współtworzyła Wielka Brytania w stosunku do niemiecko-francuskiego tandemu?

Należy jednocześnie podkreślić, że pozycja UE została nadszarpnięta jeszcze przed decyzją Wielkiej Brytanii o wystąpieniu z UE. Wyzwania polityczne (m.in. wydarzenia na Ukrainie, Bliskim Wschodzie i w Afryce Północnej), gospodarcze (m.in. globalny kryzys finansowy i gospodarczy) i społeczne (m.in. starzejące się społeczeństwo, kryzys migracyjny) przyczyniły się do głębokich podziałów i kontestowania idei europejskiej solidarności i spójności, a także osłabiły UE w środowisku międzynarodowym. Czynnikami trwale ograniczającymi siłę UE są natomiast:

- złożoność prawna i organizacyjna UE (brak wyraźnie określonego ośrodka decyzyjnego);

- odmienne priorytety i interesy polityczne, ekonomiczne, społeczne krajów i UE jako całości;

- zróżnicowanie kulturowe wielonarodowego kontynentu;

- forma i charakter wspólnej polityki zagranicznej i bezpieczeństwa - słabe instrumentarium i możliwości operacyjne, nieskuteczne rozwiązania instytucjonalne, niski budżet [Grosse 2009].

Brexit osłabia UE przede wszystkim wizerunkowo, bo pierwszy raz w historii proces integracji został odwrócony. Może też wzmacniać sceptyczną postawę innych państw wobec procesu pogłębiania współpracy i przyczyniać się do większego zainteresowania ideą integracji wybiórczej lub koncepcją Europy wielu prędkości [Borońska-Hryniewiecka i in. 2016; Möller, Oliver 2014]. Z drugiej strony, paradoksalnie, brexit można też odczytywać jako przejaw sukcesu, bo oto postawiony za cel integracji i ostatecznie wykreowany system stabilności i bezpieczeństwa w Europie stał się na tyle komfortowy, naturalny i trwały, że Wielka Brytania zdecydowała się go opuścić. Możliwa jest też sytuacja, że integracja europejska przyśpieszy, kiedy wspólnotę opuści państwo wykazujące wstrzemięźliwość wobec delegowania uprawnień do instytucji wspólnotowych oraz preferujące międzyrządowy model podejmowania decyzji (Wielka Brytania nie jest członkiem unii monetarnej ani strefy Schengen, korzysta z rabatu w składce do unijnego budżetu oraz z opt-out w obszarze sprawiedliwości i spraw wewnętrznych, była też przeciwna wzmacnianiu wspólnej polityki bezpieczeństwa i obrony). Na takim rozwoju sytuacji może najbardziej zależeć Francji, która będzie dążyła do wykorzystania brexitu do zwiększenia swoich wpływów politycznych i przekształcenia UE zgodnie z francuską wizją integracji (w szczególności w takich obszarach, jak polityka bezpieczeństwa i obrony oraz współpraca w strefie euro). Taka postawa Francji wynika z braku możliwości wykorzystania Wielkiej Brytanii jako przeciwwagi w sytuacji geopolitycz-

${ }^{7}$ Szerzej o skutkach brexitu: [Bond i in. 2016; Koczy 2016]. 
nych i historycznych antagonizmów z Berlinem oraz z ryzyka przejęcia politycznego przywództwa w UE przez Niemcy ${ }^{8}$. Można się spodziewać, że Francja będzie dążyła do zachowania równowagi sił w nowym układzie europejskim właśnie przez pogłębienie unii walutowo-gospodarczej i współpracy polityczno-obronnej (oraz wzmocnienie tandemu z Niemcami w myśl zasady ,partnerstwa dwóch równorzędnych potęg”). Należy jednak przypuszczać że ta ściślejsza współpraca gospodarczo-monetarna i militarna będzie realizowana jedynie w ramach wąskiej grupy państw [Młynarski 2017].

\section{Zakończenie}

Unia Europejska jest ważnym uczestnikiem stosunków międzynarodowych, istotnym graczem w rywalizacji geoekonomicznej i niekwestionowaną potęgą w obszarze soft power. Jednak w obliczu dokonujących się przemian $\mathrm{w}$ środowisku międzynarodowym (rosnąca siła państw Azji) i w związku z utratą jednego ze swoich najważniejszych członków potęga UE zostanie osłabiona. Brexit może też stać się początkiem rozpadu UE, jeśli w odpowiedzi na te wyzwania nie zostaną podjęte działania wzmacniające jedność Europy. Aby do tego nie dopuścić, konieczne jest zainicjowanie procesu przyspieszającego modernizację struktur, mechanizmów zarządzania i podejmowania decyzji oraz wzmocnienie polityki zagranicznej i obrony. Wciąż aktualne pozostają spostrzeżenia Kissingera [1996, s. 887] „zjednoczona Europa będzie wielkim mocarstwem, podzielona - stanie się drugorzędnym podmiotem sceny politycznej".

\section{Literatura}

Antczak A., 2012, Role międzynarodowe Unii Europejskiej. Aspekty teoretyczne, Vizja Press \& IT, Warszawa.

Barburska O., 2016, Argument sity czy siła argumentów? Unia Europejska w stosunkach międzynarodowych jako soft power, Rocznik Integracji Europejskiej, t. 10.

Białoskórski R., Kobryński R., Sułek M., 2017, Potęa państw 2017. Międzynarodowy układ sit w procesie zmian. Raport potegometryczny, ASPRA - JR, Warszawa.

Bond I., Besch S., Gostyńska-Jakubowska A., Korteweg R., Mortera-Martinez C., Tilford S., 2016, Europe after Brexit: unleashed or undone? Centre for European Reform.

Borońska-Hryniewiecka K., Kaca E., Płóciennik S., Toporowski P., 2016, Relacje Unia EuropejskaWielka Brytania po ewentualnym Brexicie - stanowiska Niemiec, Francji, Włoch, Hiszpanii i Polski, Polski Instytut Spraw Międzynarodowych, Warszawa.

Global Counsel, 2015, Brexit: Potential impact on the UK and EU, czerwiec 2015, www.globalcounsel. co.uk/system/files/publications/Global_Counsel_Impact_of_Brexit_June_2015.pdf (11.04.2018).

\footnotetext{
${ }^{8}$ Według licznych francuskich badaczy brexit oznacza więcej Niemiec w Europie i mniej Europy w świecie [Moïsi 2016].
} 
Grosse T.G., 2009, O słabości polityki zagranicznej Unii Europejskiej, Analizy Natolińskie, 8(40). https://www.globalfirepower.com/countries-listing.asp (11.04.2018).

IMP, 2017, Indeks Mocy Państw, http://index.ineuropa.pl (11.04.2018).

International Institute for Strategic Studies, 2018, https://www.iiss.org (11.04.2018).

Kissinger H., 1996, Dyplomacja, Bellona, Warszawa.

Koczy L.A., 2016, How Brexit affects European Union power distribution, Centre for Economic and Regional Studies, Hungarian Academy of Sciences, Discussion Papers MT-DP - 2016/11, Budapest.

Łoś R., 2016, Potęga - ujęcie teoretyczne: definicja, struktura i oddziaływanie, [w:] Domański T. (red.), Międzynarodowe studia polityczne i kulturowe wobec wyzwań wspótczesności, Wyd. Uniwersytetu Łódzkiego, Łódź.

Milczarek D., 2003, Rola międzynarodowa UE jako „mocarstwa niewojskowego”, Studia Europejskie, t. 1.

Młynarski T., 2017, Brexit-następstwa dla Francji i jej członkostwa w Unii Europejskiej, Krakowskie Studia Międzynarodowe, $\mathrm{nr} 2$.

Moïsi D., 2016, Brexit: plus d'Allemagne en Europe, IFRI, https://www.ifri.org/fr/espace-media/lifri-medias/brexit-plus-dallemagne-europe (12.04.2018).

Möller A., Oliver T., 2014, The United Kingdom and the European Union: What would a "Brexit" mean for the EU and other states around the world? DGAP Analyse, no. 16.

Nye J., 2007, Soft Power. Jak osiagnać sukces w polityce światowej, WAiP, Waszawa.

Organski A.F.K., 1967, World Politics, Knopf, New York.

Parzymies S., 2009, Unia Europejska jako uczestnik stosunków międzynarodowych, [w:] Parzymies S. (red.), Dyplomacja czy siła? Unia Europejska w stosunkach międzynarodowych, Wydawnictwo Naukowe Scholar, Warszawa.

Soft Power 30, A global ranking of soft power 2017, https://softpower30.com/wp-content/uploads/2017/07/The-Soft-Power-30-Report-2017-Web-1.pdf (11.04.2018).

Stoessinger J.G., 1967, The Might of Nations, McGraw-Hill College, New York.

Sułek M., 2013, Potęa państw. Modele i zastosowania, Rambler, Warszawa. 